\title{
Isolation of Three Bioactive Phenantroindolizidine Alkaloids from the Fruit Latex of Ficus botryocarpa Miq
}

Jayson Wau ${ }^{1 *}$, David Timi ${ }^{1}$, Anthony Harakuwe ${ }^{1}$, Bruce Bowden ${ }^{2}$, Cherie Motti ${ }^{3}$, Harry Sakulas ${ }^{4}$ and Rag Gubag-Sipou ${ }^{1}$

${ }^{1}$ Department of Applied Sciences, PNG University of Technology, PMB, Lae, Papua New Guinea

${ }^{2}$ School of Pharmacy and Molecular Science, James Cook University, Molecular Science Building DB21, Townsville Campus, Australia

${ }^{3}$ Australian Institute of Marine Science, PMB No 3, Townsville Mail Center, Q 4810, Australia

${ }^{4}$ Environment Research Management Centre, PNG University of Technology, PMB, Lae, Papua New Guinea

\begin{abstract}
Latex of $F$. botryocarpa fruit is applied on skin infections in Papua New Guinea ethnotherapeutic practices. Systematic bioassay guided separation and isolation of subsequent fractions of latex extracts resulted in three bioactive fractions. Structures were determined by physical (M.pt and $\mathrm{R}_{f}$ values) and spectroscopic (1D- ${ }^{1} \mathrm{H}$ NMR, 2D-HSQC NMR, 2D-HMBC NMR) and MS ESI-POS. The two methylene protons $(2 \mathrm{H}-1)$ and $2 \mathrm{H}-3)$ resonate as triplets at $\delta 3.59$ and $\delta 4.99$ respectively. Electron dense $\delta 4.99(2 \mathrm{H}-3)$ on $(\mathrm{C}-3)$ depicts the strong electron withdrawing component, quaternary nitrogen $\left(=\mathrm{N}=^{+}\right)$. Protons resonating at $\delta 3.88$ and $\delta 3.89$ are singlets depicting two methoxy groups. Both $\delta 3.88$ and $\delta 3.89$ are para-aryls substituents. All isolates, (1), (2) and (3) were identified to be ficuseptine. 2D-NMR and MS of (2) found it to be ficuseptine chloride "2, 3-dihydro-6, 8-bis (4-methoxyphenyl)-1,2,3-trihydroindolizidinium chloride". The counter ions were not established and provide promising lead for further investigation.
\end{abstract}

Keywords: Ficus botryocarpa; Latex; Antimicrobial activity; Ficuseptine; Skin infection

\section{Introduction}

Fruit latex of F. botryocarpa was used to treat sores, wounds and other superficial skin infections in East Sepik Province, Papua New Guinea (PNG) [1-3]. Staphylococci are the principal causative agents accounting for $30 \%$ to $50 \%$ of wound infections [4]. Preliminary antimicrobial screening has shown activity of methanol extract of latex (FL) on Staphylococcus albus and Staphylococcus aureus with inhibition zones of $28 \mathrm{~mm}$ and $26 \mathrm{~mm}$ respectively [5-7].

Investigation of the active constituents from the latex of $F$. botryocarpa centered on alkaloids. Raw fruit latex was extracted with methanol and filtered separating the bioactive filtrate (F2) from the non-bioactive filtered (F1). (F2) was confirmed as predominantly alkaloids by Dragendorff and Mayers test [8]. By means of preparative chromatography three fractions, (1), (2) and (3) were isolated from (F2). These fractions showed strong activity against Escherichia coli, S. aureus and two bacterial colonies types isolated from an infected folliculitis [9]. This study attempts to identify chemical structures of these alkaloid isolates.

\section{Materials and Methods}

\section{Sampling}

Pricked fruits with latex protruding from petiole and fruit bud were collected in $40 \mathrm{ml}$ polyethylene sampling bottles at Bulolo, PNG.

\section{Sample preparation}

Combined latex, $18 \mathrm{ml}$ was extracted with $50 \mathrm{ml}$ methanol and subject to vibration in a flask shaker (Stuart FS-1) at 200 oscillations per minute for 20 minutes. The process was repeated three times to obtain the primary extract (FL). Insoluble (F1) and soluble (F2) fractions were recovered by gravity filtration using $125 \mathrm{~mm}$ and $185 \mathrm{~mm}$ using whatman filter papers and concentrated on a BUCHI rotary evaporator under reduced pressure followed by drying under vacuum.

White gummy-like substance, were collected as filtered (F1) and air dried at room condition to solidify. The soluble filtrate (F2) was concentrated on a BUCHI rotary evaporator under reduced pressure followed by vacuum drying. (F2) gave a golden - yellow paste.
$1 \mathrm{~g}$ of $\mathrm{F} 2$ was dissolved in $10 \mathrm{ml} \mathrm{MeOH}$ and deposited on a horizontal thin line at the bottom of a preparative silica gel plate. The plate was placed in a chamber containing the solvent, acetone/toluene/ ethanol/ammonia (40:40:6:2) mixture [10]. Three spots of $\mathrm{R}_{f} 0.26, \mathrm{R}_{f} 0.14$ and $\mathrm{R}_{f} 0.07$ resembling bands developed earlier were ideally developed (blue fluorescence) and marked under UV light at $254 \mathrm{~nm}$. The three fractions were scraped off the glass plate $(20 \times 20 \mathrm{~cm})$ into separate screw cap conical flask $(100 \mathrm{ml})$. Each fraction was dissolved in $\mathrm{Me} \mathrm{OH}$ $(3 \times 30 \mathrm{ml})$ vibrated at 200 oscillations per minute for 10 minutes and filtered. The filtrates were concentrated in vacuo at $68^{\circ} \mathrm{C}(\mathrm{BUCHI})$ and further vacuum dried yielding fraction (1) $2.10 \mathrm{mg}$, (2) $4.20 \mathrm{mg}$ and (3) $6.13 \mathrm{mg}$.

\section{Instruments}

Melting Point Instrument, Digital 9000 Series, IA9100 230 V (max. $370^{\circ} \mathrm{C}$ ), Clarkson, USA. Melting points were determined by inserting glass capillaries filled with samples to electrothermal melting point apparatus hovels and the values are uncorrected.

NMR spectra were obtained using Varian Unity Inova $300 \mathrm{MHz}$ using VNMRJ software and Bruker Avance spectrometer $(600 \mathrm{MHz})$ equipped with a cryoprobe operated using Top Spin software. $\mathrm{CD}_{3} \mathrm{OD}$ used as reference $\left(1 \mathrm{D}, \delta=49.0 \mathrm{ppm}\left({ }^{13} \mathrm{C}\right)\right.$ and $3.31 \mathrm{ppm}\left({ }^{1} \mathrm{H}\right)$, whilst $2 \mathrm{D}$ $\left.\delta=0.00\left({ }^{1} \mathrm{H}\right) \mathrm{ppm}\right)$.

High resolution mass spectral data were determined on a Bruker BioApex 47 Fourier transform mass spectrometer (FTMS) with an electrospray (ESI) all event sequences were controlled and data reduction performed using Bruker Daltonics XMASS version 7.0.3.0 software.

*Corresponding author: Jayson Wau, Department of Applied Sciences, PNG University of Technology, PMB, Lae, Papua New Guinea 675, Tel: +675- 4734551; E-mail: jswau0@gmail.com

Received November 04, 2015; Accepted November 22, 2015; Published November 24,2015

Citation: Wau J, Timi D, Harakuwe A, Bowden B, Motti C, et al. (2015) Isolation of Three Bioactive Phenantroindolizidine Alkaloids from the Fruit Latex of Ficus botryocarpa Miq. Nat Prod Chem Res 3: 197. doi:10.4172/2329-6836.1000197

Copyright: () 2015 Wau J, et al. This is an open-access article distributed under the terms of the Creative Commons Attribution License, which permits unrestricted use, distribution, and reproduction in any medium, provided the original author and source are credited. 


\section{Results and Discussion}

The three fractions showed distinct separation on the chromatogram evident with M.pt and $\mathrm{R}_{f}$ values (Table 1). However, ${ }^{1} \mathrm{H}-\mathrm{NMR}$ spectral information of the three isolates corresponded with literature information of ficuseptine chloride, 2, 3-dihydro-6, 8-bis (4-methoxyphenyl)-, 1H-Indolizinium chloride, (Figure 1).

Structures were determined by physical (M.pt and $\mathrm{R}_{f}$ values), chemical (phytochemical screening), spectroscopic (1D- ${ }^{-} \mathrm{H}$ NMR, 2D-HSQC NMR and 2D-HMBC NMR) methods and comparison with literature data (Table 2) [11].

\section{Structural elucidation}

Ficuseptine (2) was obtained as second fraction from preparative chromatography of (F2). Vacuum drying gave orange-like paste $(4.20$ mg), M.pt $213-215^{\circ} \mathrm{C}$ and $\mathrm{R}_{f} 0.14$ with minor impurities [11].

Proton NMR assignments compared with literature values of ficuseptine chloride and showed exceptional resemblance, (Table 2).

The two methylene protons $(2 \mathrm{H}-1)$ and $(2 \mathrm{H}-3)$ resonate as triplets at $\delta 3.59$ and $\delta 4.99$ respectively. Electron dense $\delta 4.99$ (2H-3) on (C3 ) depicts the strong electron withdrawing component, quaternary nitrogen $\left(=\mathrm{N}=^{+}\right)$.

\begin{tabular}{|c|c|c|}
\hline Fraction & M.pt $\left.{ }^{\circ} \mathbf{C}\right)$ & $\mathbf{R}_{\boldsymbol{f}}$ \\
\hline 1 & $220-221$ & 0.26 \\
\hline 2 & $213-215$ & 0.14 \\
\hline 3 & $218-220$ & 0.07 \\
\hline
\end{tabular}

Table 1: Physical test results of the three isolates.
Protons resonating at $\delta 3.88$ and $\delta 3.89$ are singlets depicting two methoxy groups. Both $\delta 3.88$ and $\delta 3.89$ are para-aryls substituents. The methines $\delta 9.13$ and $\delta 8.60$ are singlets depicting two lone protons on the indolizidinium aryl component.

HMBC correlations of $\delta 33.1$ from $\delta 2.55\left({ }^{2} J 2 \mathrm{H}-2\right)$ and $\delta 4.99\left({ }^{3} J\right.$ $2 \mathrm{H}-3), \delta 22.6$ from $\delta 4.99\left({ }^{2} J 2 \mathrm{H}-3\right)$ and $\delta 60.9$ from $\delta 2.55\left({ }^{2} J 2 \mathrm{H}-2\right)$ and $\delta 3.59\left({ }^{2} J 2 \mathrm{H}-1\right)$ is evident the methylene groups comprised in a discrete spin system. The H-C HMBC coupling pattern suggests that the methylene groups are interconnected in a planner system. The high chemical shift of methylene $\delta 60.9$ (C-3) depicts connection to positively charged electronegative element $(=\mathrm{N}=)^{+}$.

Signal at $\delta 3.59$ ppm shows HMBC correlation to the quaternary acetyl carbon, $\delta 155.3\left({ }^{2} J \mathrm{C}-9\right)$. This signifies the three methylene groups, the quaternary nitrogen and carbon constitutes a five-membered ring system. Chemical shift at $\delta 155.3 \mathrm{ppm}$ shows long range correlations from, $\delta 8.60\left({ }^{3} \mathrm{~J} 1 \mathrm{H}-7\right), \delta 4.99\left({ }^{3} \mathrm{~J} 2 \mathrm{H}-3\right)$ and $\delta 9.13\left({ }^{3} \mathrm{~J} 1 \mathrm{H}-5\right)$. More so, $\delta 9.13$ convinces that its bonding carbon is directly bonded to the quaternary nitrogen; hence, depicting that the five-membered spin system is joined adjacent to an aromatic ring (Figure 2).

2D NMR correlation analysis of ${ }^{13} \mathrm{C}$ to ${ }^{1} \mathrm{H}$ vice versa via $\mathrm{HSQC}$ and HMBC. ${ }^{n} J$ denoting long range correlations beyond ${ }^{3} J$. Coupling constants $J(\mathrm{~Hz})$ were measured from 1D NMR spectra. Quaternary carbons were derived from correlation analysis of ${ }^{1} \mathrm{H}$ to ${ }^{13} \mathrm{C}$ via $\mathrm{HMBC}$ (Table 3).

The two singlets resonating at $\delta 8.60$ and $\delta 9.13$ in the aromatic ring is likely in long range ${ }^{1} \mathrm{H}-{ }^{1} \mathrm{H}$ coupling at meta-meta positions. Their correlations to the quaternary $\delta 140.4\left({ }^{2} J_{\mathrm{C}-6}\right)$ and the presence of

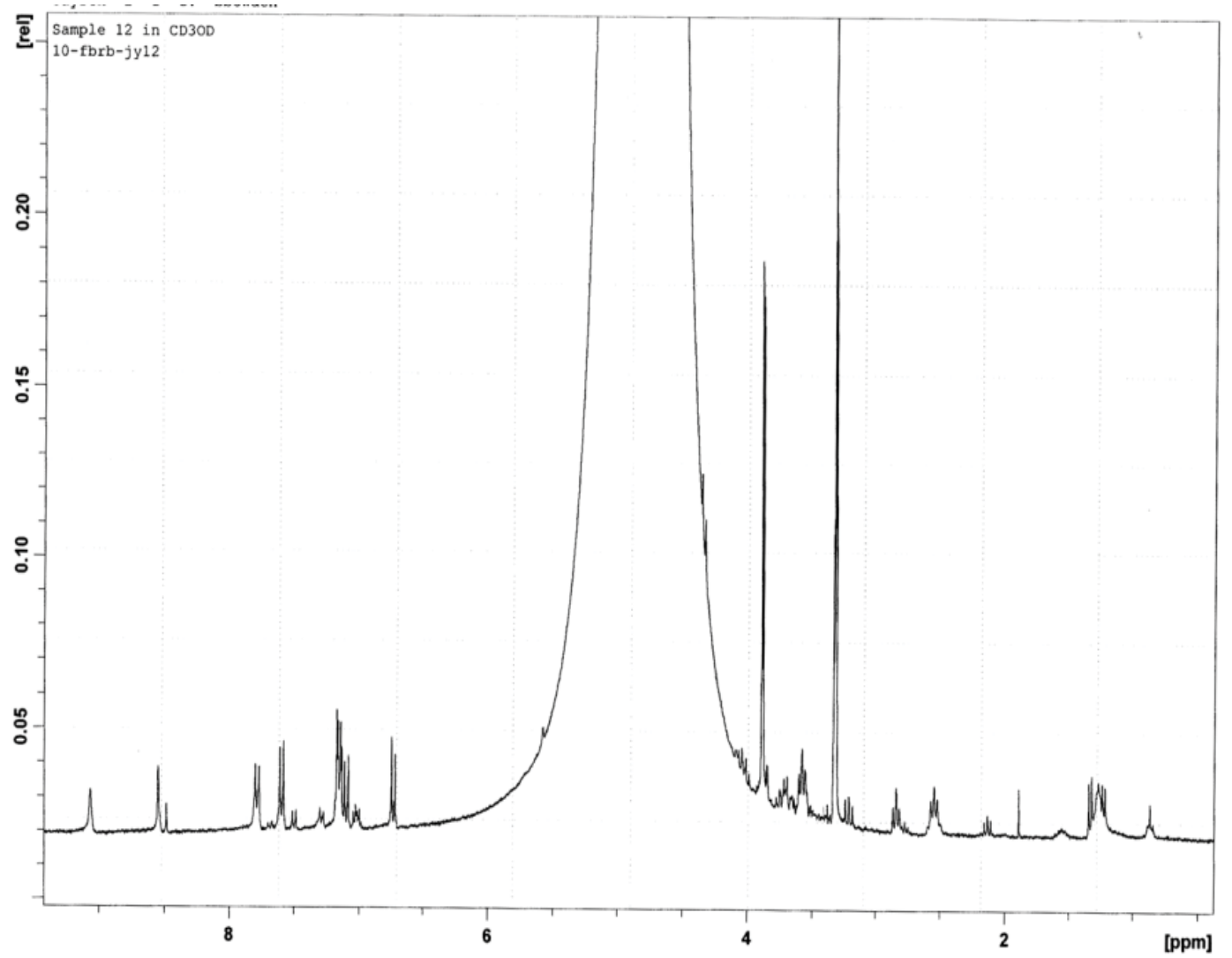

Figure 1: 1D-1 H NMR spectrum of (2) 
Citation: Wau J, Timi D, Harakuwe A, Bowden B,Motti C, et al. (2015) Isolation of Three Bioactive Phenantroindolizidine Alkaloids from the Fruit Latex of Ficus botryocarpa Miq. Nat Prod Chem Res 3: 197. doi:10.4172/2329-6836.1000197

Page 3 of 5

\begin{tabular}{|c|c|c|}
\hline \multirow{2}{*}{${ }^{1} \mathbf{H}$} & \multicolumn{2}{|c|}{$\boldsymbol{\delta}(\mathbf{p p m})$} \\
\cline { 2 - 3 } & $\mathbf{( 2 )}$ & Ficuseptine-Cl \\
\hline $1-\left(\mathrm{C}-\mathrm{H}_{2}\right)$ & 3.59 & 3.54 \\
\hline $3-\left(\mathrm{C}-\mathrm{H}_{2}\right)$ & 4.99 & 5.45 \\
\hline $4-$ & - & - \\
\hline $5-(\mathrm{C}-\mathrm{H})$ & 9.13 & 10.09 \\
\hline $7-(\mathrm{C}-\mathrm{H})$ & 8.60 & 8.20 \\
\hline 4'OMe - $\left(\mathrm{C}-\mathrm{H}_{3}\right)$ & 3.88 & 3.80 \\
\hline 4"OMe - $\left(\mathrm{C}-\mathrm{H}_{3}\right)$ & 3.89 & 3.80 \\
\hline
\end{tabular}

Table 2: ${ }^{1} \mathrm{H} \delta$ comparison of (2) with ficuseptine- $\mathrm{Cl}(4)$.

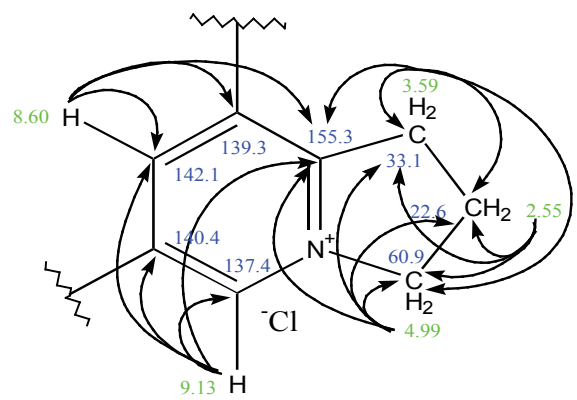

Figure 2: HMBC / HSQC correlations of the indolizidinium moiety.

\begin{tabular}{|c|c|c|c|c|}
\hline \multirow[t]{2}{*}{ C } & \multicolumn{3}{|c|}{$\delta(p p m)$} & \multirow[b]{2}{*}{${ }^{1} \mathrm{H}-{ }^{3} J(\mathrm{gHMBC})$} \\
\hline & ${ }^{13} \mathrm{C}$ & ${ }^{1} \mathrm{H}-{ }^{1} J(H S Q C)$ & ${ }^{1} \mathrm{H}-{ }^{2} \mathrm{~J}(\mathrm{gHMBC})$ & \\
\hline 1 & 33.1 & $3.59, \mathrm{t}, 1.8 \mathrm{~Hz}, 2 \mathrm{H}-1$ & $2.55(2 \mathrm{H}-2)$ & $4.99(2 \mathrm{H}-3)$ \\
\hline 2 & 22.6 & $\begin{array}{c}\text { 2.55, quintet, } 6.4= \\
3.1 \mathrm{~Hz}, 2 \mathrm{H}-2\end{array}$ & $4.99(2 \mathrm{H}-3), 3.59$ & - \\
\hline 3 & 60.9 & $4.99, \mathrm{t}, 1.6 \mathrm{~Hz}, 2 \mathrm{H}-3$ & $(2 \mathrm{H}-1) 2.55(2 \mathrm{H}-2)$ & $3.59(2 \mathrm{H}-1)$ \\
\hline 5 & 137.4 & $9.13, \mathrm{~s}, 1 \mathrm{H}-5$ & & $8.60(1 \mathrm{H}-7)$ \\
\hline 6 & 140.4 & - & $\begin{array}{c}9.13(1 \mathrm{H}-5), 8.60 \\
(1 \mathrm{H}-7)\end{array}$ & 7.80 (1H-2') \\
\hline 7 & 142.1 & $8.60, \mathrm{~s}, 1 \mathrm{H}-7$ & & $9.13(1 \mathrm{H}-5)$ \\
\hline 8 & 139.3 & - & & $7.60(1 \mathrm{H}-3 ")$ \\
\hline 9 & 155.3 & - & $3.59(2 \mathrm{H}-1)$ & $\begin{array}{c}8.60(1 \mathrm{H}-7), 9.13 \\
(1 \mathrm{H}-5), 4.99(1 \mathrm{H}-3)\end{array}$ \\
\hline $1^{\prime}$ & 126.8 & - & - & $8.60(1 \mathrm{H}-7)$ \\
\hline $2^{\prime}$ & 129.6 & 7.80, d, $1.8 \mathrm{~Hz}, \mathrm{H}-2$ ' & - & - \\
\hline 5 & 115.8 & 7.14, d, $4.1 \mathrm{~Hz}, 1 \mathrm{H}-5$ & - & - \\
\hline $1 "$ & 127.7 & - & - & $\begin{array}{c}8.60(1 \mathrm{H}-7), 7.14 \\
(1 \mathrm{H}-2 ")\end{array}$ \\
\hline $2 "$ & 130.9 & $\begin{array}{c}\text { 7.15, dd, } 8.2=4.1 \\
\mathrm{~Hz}, 1 \mathrm{H}-2 "\end{array}$ & - & 7.60 (1H-3") \\
\hline $5 "$ & 115.5 & $7.60, \mathrm{~d}, 1.7 \mathrm{~Hz}, 1 \mathrm{H}-5$ & - & - \\
\hline 4'OMe & 55.8 & 3.88 , s-br, 3H-4' & - & - \\
\hline 4"OMe & 55.7 & 3.89, s-br, $3 \mathrm{H}-4 "$ & - & - \\
\hline
\end{tabular}

Table 3: $2 \mathrm{D}-\mathrm{HSQC}$ and $\mathrm{HMBC}$ correlation assignments at selected proton and carbon systems of (2).

the other quaternary carbon $\delta 139.3$ denotes ortho-para disubstituted carbons. Hence, depicting 1, 2, 3-trihydroindolizidinium moiety (Figure 3).

$1 \mathrm{D}-\mathrm{NMR}$ showed two doublets at $\delta 7.80$ and $\delta 7.60 \mathrm{ppm}$ accounting for two protons each, whilst, the doublet of doublet at $\delta 7.14$ accounts for four protons. ${ }^{1} \mathrm{H}-{ }^{1} \mathrm{H}$ coupling of $\delta 7.80$ with $\delta 7.14$ and $\delta 7.60$ with $\delta$ 7.14 depict two para-substituted aryl groups.

$\delta 7.80 \mathrm{HMBC}$ correlations to the quatenary $\delta 140.4\left({ }^{3} J_{1 \mathrm{H}-2}\right)$ and $\delta$ $162.8\left({ }^{3} J_{1 \mathrm{H}-2}\right)$ indicates that $\delta 129.6$ is part of one para-substituted aryl bonded at position C- 6 of the indolizidine moiety. $\delta 162.8$ suggests the para-substiuent has high deshielding effect. Two protons resonating as dublets at $\delta 7.80$ are likely on the ortho (2'), (6') positions coupling to the doublet $\delta 7.14$ at meta ( $\left.3^{\prime}\right)$, and ( $\left.5^{\prime}\right)$ positions. Singlet at $\delta 3.88$ shows direct correlation to $\delta 55.8$ and attributed as a methoxy group, hence, is the ideal para-substituent.

$\delta 8.60 \mathrm{HMBC}$ correlations to the quaternary $\delta 127.7\left({ }^{3} J_{\mathrm{C}-1 \mathrm{n}}\right)$ depicts association of the indolizidine moiety at position C-8 to the other parasubstituted aryl group. $\delta 7.14 \mathrm{HMBC}$ correlations to $\delta 127.7\left({ }^{2} J_{\mathrm{C}-2^{\prime \prime}}\right)$ and $\delta 162.1\left({ }^{3} J_{\text {OMe }-4^{\prime \prime}}\right)$ indicates that $\delta 129.6$ is part of one para-substituted aryl bonded at position C- 6 of the indolizidine moiety. $\delta 162.1$ suggests the para-substiuent is a high shielding element. Two protons resonating as doublets at $\delta 7.60$ are likely on the meta (3")-meta (5") positions coupling to the doublet of doublet $\delta 7.14$ at ortho (2")-ortho (6") positions. Singlet at $\delta 3.89$ shows direct correlation to $\delta 55.7$ and attributed as a methoxy group, hence, is the ideal para-substituent (Figure 4).

Main peak in the spectrum is $m / z 332.1645$ which matches exactly with the calculated ion for ficuseptine, $\mathrm{C}_{22} \mathrm{H}_{22} \mathrm{O}_{2} \mathrm{~N}^{+}, m / z 332.1645$. The expected ${ }^{13} \mathrm{C}$ signal is present at 333.1677 , however, there is still a very small signal at 333.1714. Expected deuterated ion $\mathrm{C}_{22} \mathrm{H}_{21} \mathrm{DO}_{2} \mathrm{~N}^{+}, \mathrm{m} / z$

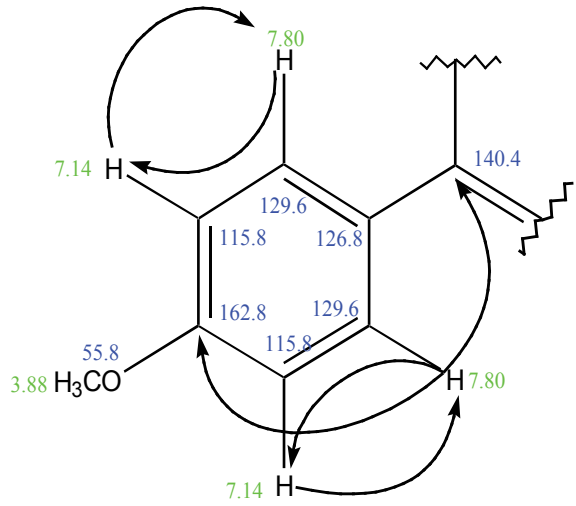

Figure 3: $\mathrm{HMBC}$ correlations and $\mathrm{H}-\mathrm{H}$ splitting of a para - substituted aryl group at position C-6 of indolizidinium moiety.

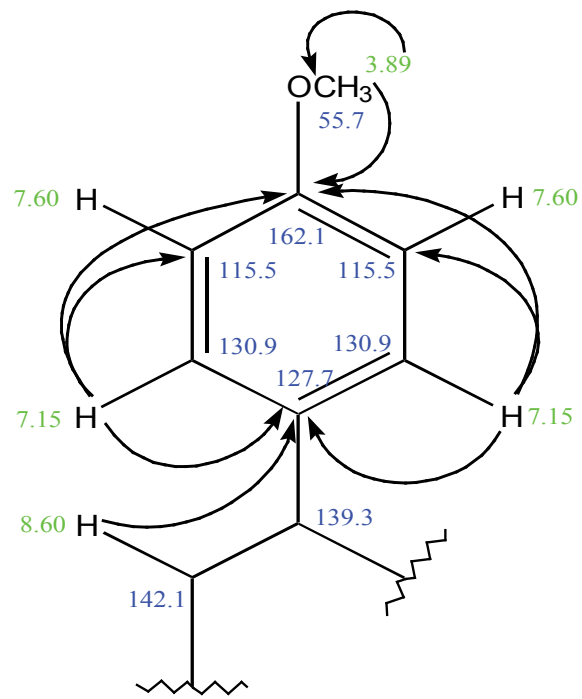

Figure 4: HMBC correlations depicting association of a para-substituted. 
333.1708 is within 1 ppm of the peak observed at 333.1706 (Figure 5).

The compound was established as ficuseptine chloride (2) on the basis of $1 \mathrm{D}^{1} \mathrm{H}-\mathrm{NMR}, 2 \mathrm{D}$ HSQC and HMBC spectroscopy, MS, melting point $\left(213-215^{\circ} \mathrm{C}\right)$ and TLC analysis. Moreover, comparison with literature confirms the compound to be ficuseptine chloride (Figure 1), ruling out possibilities of $\mathrm{N}$-oxides counter ions [11,12] (Figure 6).

Small quantity of fraction (1) was transferred to a NMR tube and dissolved in $1 \mathrm{ml} \mathrm{CD} \mathrm{OD}_{3}$ and analysed by Varian Mercury $300 \mathrm{MHz}$ NMR at 10 scans. ${ }^{1} \mathrm{H} \mathrm{nmr} \delta$ (CD $\left.\mathrm{OD}\right): 9.07(\mathrm{~s}, 1 \mathrm{H}-5), 8.54$ (s, $\left.1 \mathrm{H}-7\right), 7.85$ (d, $J=1.8 \mathrm{~Hz}, \mathrm{H}-2$ ' and $\left.\mathrm{H}-6{ }^{\prime}\right), 7.60\left(\mathrm{~d}, J=1.7 \mathrm{~Hz}, 1 \mathrm{H}-3^{\prime \prime}\right.$ and $\left.1 \mathrm{H}-5^{\prime \prime}\right), 7.15$ (dd, $8.4=4.1 \mathrm{~Hz}, 1 \mathrm{H}-3^{\prime}, 1 \mathrm{H}-5$ ', $1 \mathrm{H}-2$ " and , $1 \mathrm{H}-6$ "), 4.99 (t, $J=1.6 \mathrm{~Hz}, 1 \mathrm{H}-$ 3), 3.89 (s-br, $3 \mathrm{H}-4$ "), 3.88 (s-br, $3 \mathrm{H}-4$ '), 3.57 (t, $J=1.8 \mathrm{~Hz}, 1 \mathrm{H}-1)$ and 2.55 (quart, $J=6.4,3.1 \mathrm{~Hz}, 1 \mathrm{H}-2$ ) $\mathrm{ppm}$.

The compound was identified as ficuseptine (1) on the basis of its ${ }^{1} \mathrm{H}-\mathrm{NMR}$ spectral comparison with ficuseptinechloride (4) and other literature data ( $\mathrm{R}_{f}$ and melting point) $[11,12]$ (Figure 7 ).

Small quantity of fraction (3) was transferred to a NMR tube and dissolved in $1 \mathrm{ml} \mathrm{CD}$ OD and analysed by Varian Mercury $300 \mathrm{MHz}$ $\mathrm{NMR}$ at 10 scans. ${ }^{1} \mathrm{H} \mathrm{nmr} \delta$ (CD $\mathrm{OD}$ ): 9.06(s, 1H-5), 8.52 (s, 1H-7),

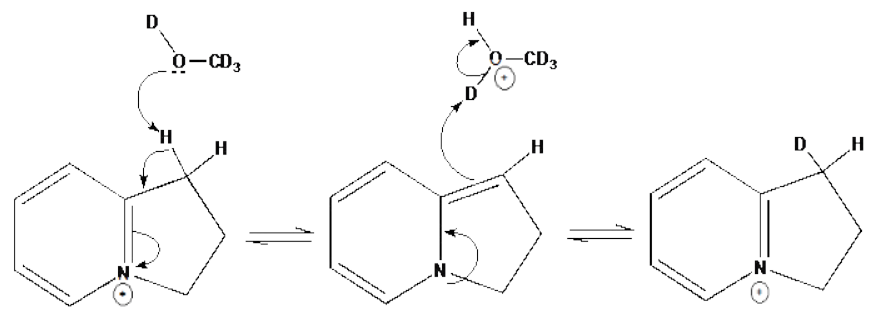

Figure 5: Indolizidine moiety showing mass spectral fragments.

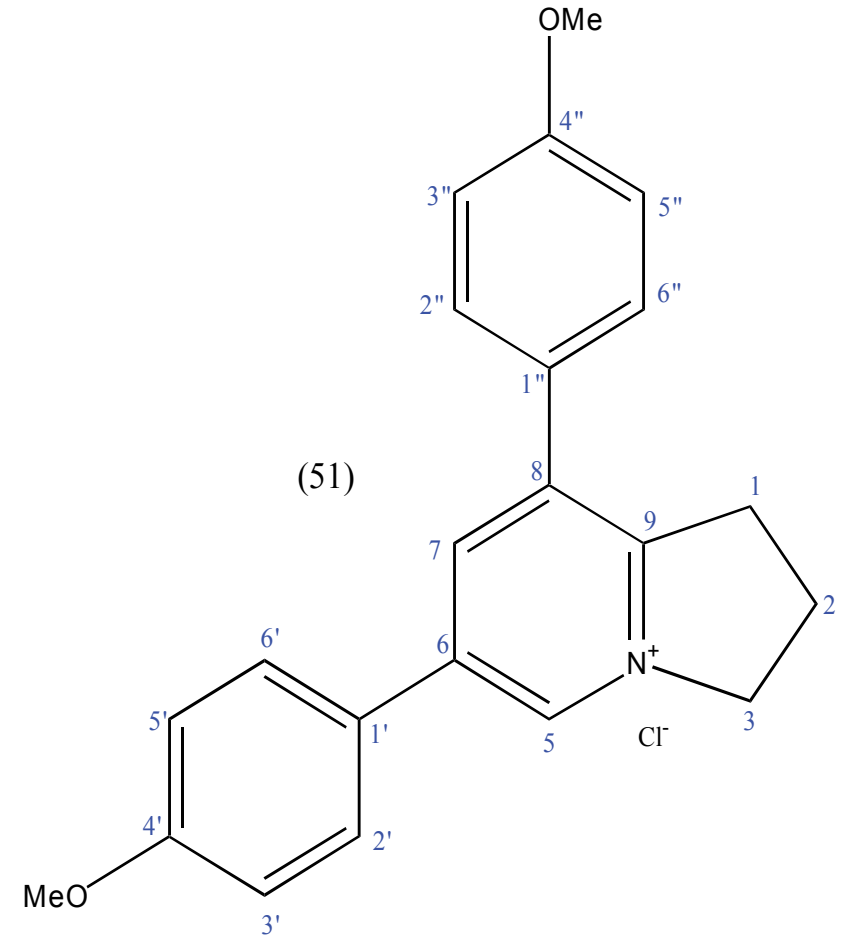

Figure 6: Structure of ficuseptine chloride (2).

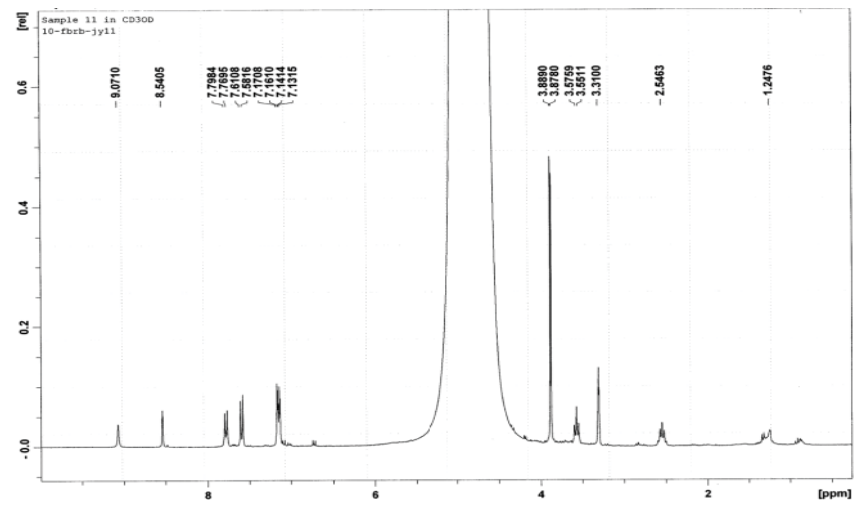

Figure 7: ${ }^{1} \mathrm{H}-\mathrm{NMR}$ spectrum of fraction (1) with peak picks.

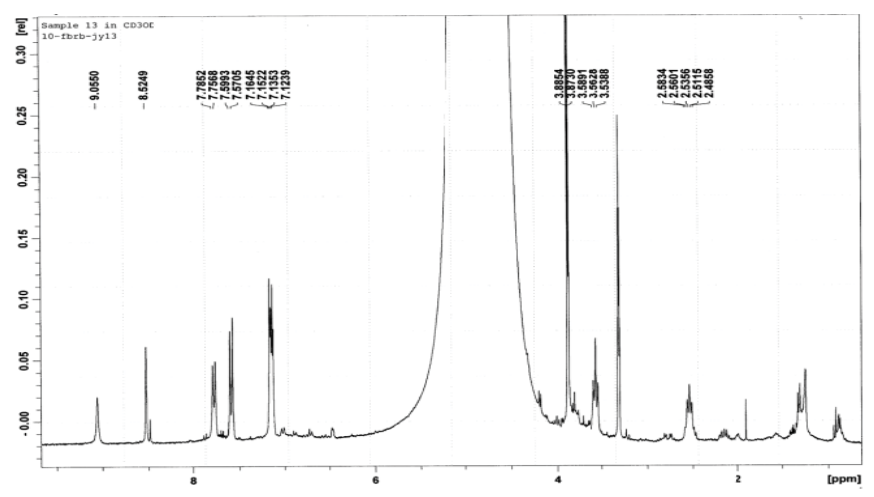

Figure 8: ${ }^{1} \mathrm{H}-\mathrm{NMR}$ spectrum of fraction (3) with peak pick.

7.77 (d, $J=1.8 \mathrm{~Hz}, \mathrm{H}-2$ ' and H-6'), 7.59 (d, $J=1.7 \mathrm{~Hz}, 1 \mathrm{H}-3$ " and $\left.1 \mathrm{H}-5^{\prime \prime}\right)$, 7.14 (dd, 8.4=4.1 Hz, 1H-3', 1H-5', 1H-2" and ,1H-6"), 4.99 (t, J=1.6 Hz, 1H-3), 3.89 (s-br, 3H-4"), 3.87 (s-br, 3H-4'), 3.56 (t, $J=1.8 \mathrm{~Hz}, 1 \mathrm{H}-$ 1) and 2.54 (quart, $J=6.4,3.1 \mathrm{~Hz}, 1 \mathrm{H}-2$ ) ppm.

The compound was identified as ficuseptine (1) on the basis of its ${ }^{1} \mathrm{H}-\mathrm{NMR}$ spectral comparison with ficuseptinechloride (4) and other literature data ( $\mathrm{R}_{f}$ and melting point) $[11,12]$ (Figure 8 ).

The compound was identified as ficuseptine (3) on the basis of its ${ }^{1} \mathrm{H}-\mathrm{NMR}$ spectral comparison with ficuseptine chloride (2), ficuseptine (1) and other literature data ( $\mathrm{R}_{f}$ and melting point) $[11,12]$.

\section{Conclusion}

Spectroscopic assessment with 1H-NMR, 13C-NMR, IR and MS showed all fractions, (1), (2) and (3) to be ficuseptine. Fraction (2) was determined to be ficuseptine chloride based on ${ }^{1} \mathrm{H}-\mathrm{NMR},{ }^{13} \mathrm{C}-\mathrm{NMR}$, IR and MS data. This is the first time this compound was reported in F. botryocarpa. With consistent spectral data fractions (1), (2) and (3) are ficuseptine bearing different anionic components. These ficuseptine derivatives are extremely polar and cationic. It was found that the fruit latex is not active in wet weather [6]. This may indicate that the stable ficuseptine is of bioactive significance vice versa.

More-over there appears an association between the gummy precipitate (F1) and the milky latex (FL) synonymous of the ficuseptine behaving as an emulsifying agent.

The ficuseptine derivatives are reported as chlorides, though the natural anionic form of the three isolated ficuseptine derivatives were 
Citation: Wau J, Timi D, Harakuwe A, Bowden B,Motti C, et al. (2015) Isolation of Three Bioactive Phenantroindolizidine Alkaloids from the Fruit Latex of Ficus botryocarpa Miq. Nat Prod Chem Res 3: 197. doi:10.4172/2329-6836.1000197

not established. Further work is necessary to isolate the three ficuseptine derivatives in their natural form and confirm the emulsification claim.

\section{Acknowledgements}

The authors thank the PNG University of Technology Research Committee for funding the study. Dr. S. Akoitai, Applied Science, Department for bioassay and phytochemical screening, Mr. K. Aubeta, Bulolo University College for the plant identification and Prof. Juergen Reichardt, School of Pharmacy and Molecular Science, James Cook University, Australia for spectral analysis.

\section{References}

1. Hemmatzadeh F, Fatemi A, Amini F (2003) Therapeutic Effects of Fig Tree Latex on Bovine Papillomatosis. J Vet Med B Infect Dis Vet Public Health 5: 473-476.

2. Abid TA, Ali KA (2014) Proteolytic versus surgical removal: The therapeutic effect of fig tree latex (Ficus carica $L$ ) on cutaneous and diphtheric forms of avian pox in pigeons (Columba domestica). Iraqi Journal of Veterinary Sciences 28: 49-53.

3. Berger S (2010) Infectious Diseases of Papua New Guinea. Los Angeles, Gideon Informatics Inc. pp. 27-51.

4. Bowler PG, Duerden BI, Armstrong DG (2010) Wound Microbiology and Associated Approaches to Wound Management. Clin Microbiol Rev 14: 244-269.
5. Timi D (1993) Preliminary Assessment of Antibacterial Activity of some Traditional Medicinal Plants in Morobe Province (Proceedings). Biological Society of New Guinea, Wau Ecology Institute, Morobe. p. 79.

6. Wau JS, Harakuwe AH, Timi D, Sakulas H, Gubag SR, et al. (2009) Studies on PNG Medicinal plants: Is the Antibacterial Activity of the Latex from Ficus Botryocarpa Dependent on the Weather? Environment Papua New Guinea Journal 2: 14-16.

7. Harborne BJ (1984) Phytochemical Methods. (2nd edn) Chapman and Hall New York. pp. 12-20

8. Wau JS, Harakuwe AH, Timi D, Sakulas H, Gubag SR, et al. (2010) Antimicrobial and chemical screening of Ficus botryocarpa. Journal of ICPNG 3: 15-19.

9. Wau JS, Harakuwe AH, Timi D, Sakulas H, Gubag SR, et al. (2010) Antimicrobial guided isolation of the three bioactive constituents from Ficus botryocarpa latex. International Conference on Folk and Herbal Medicine Proceedings. Katewa SS, Ed. Scientific Pub, Udaipur, India. pp. 66-69.

10. Bladt S, Wagner H, Zgainski EM (1984) Plant Drug Analysis. Springer-Verlage, Berlin, Germany. pp. 145-149.

11. Baumgartner B, Erdelmeir CAJ, Wright AD, Rali T, Sticher O (1990) An antimicrobial alkaloid from Ficus septica. Phytochemistry 29: 3327-3330.

12. Sheng W, Pei-Lin, Tian-Shung W (2005) Phenanthroindolizidine alkaloids from the stems of Ficus septica. Journal of Natural Products 68: 1071-1075. 